\title{
Editorial: Implicit Price Control
}

Welfare economics, cost-benefit analysis and operational research are special fields whose flowers and weeds bloom and wither out of sight and mind of most philosophers. Yet these studies are developments from within political economy, and when economics was known by that name it was at home in books and departments of philosophy, living even if sometimes quarrelling with the other moral sciences. It was a matter of course that Hume and Adam Smith, Sidgwick and Mill, should work on both sides of what was then a distinction but not a divide. In our own century Lord Keynes and Sir Roy Harrod have contributed to philosophy as well as to economics. The separation could be made complete only at a high cost: philosophy would be deprived of one of its few practical applications; economists, administrators and politicians would be too easily allowed to disguise as matters for experts many questions on which the citizen has something to say and a right to be heard. Some of them are matters of life and death.

It is easier to keep a philosophical eye on the pundits when some of them see for themselves how to distinguish science from policy and an expert witness from a propagandist. Professor Peter Self was appropriately philosophical in his lecture 'Techniques and Values in Policy Decisions' (in Nature and Conduct, edited by R. S. Peters, Royal Institute of Philosophy Lectures, Volume 8, 1973-74): 'The difficulty is to know what really is being achieved by translating into technical language differences of political and ethical opinion, and by assigning to those differences a greater degree of precision than their essentially flexible and argumentative character would seem to permit'. But he did see a useful role for cost-benefit analysis in the discussion of questions of public policy:

If we want to make out a brief for CBA we have to use a very modified version of the technique as an instrument of policy criticism, not as a positive instrument for decision or arbitration. It cannot be the latter because there is no authoritative way of defining and evaluating the 'interests' involved in a decision. But this is not the end of the matter because it certainly is the case that public action places an 'implicit price' upon all sorts of things that are not normally bought or sold. The implicit price is the resource cost that government is prepared to pay to achieve or to avoid some result. There are all sorts of problems about the measurement of resource costs, but at least respectable attempts can be made; and it is always worth trying to know costs even if we cannot measure the benefits in economic terms. If CBA supposes that it can measure these benefits in an independent and value-free way it becomes 


\section{Editorial}

foolish; but if it is used simply to question the rationale of implicit prices and to point to apparent inconsistencies among these prices, it can become a useful tool of social criticism.

Philosophical controversy has broken out even in the trade journals of the cost-benefit and operational research specialists, and is conducted with as much vigour and plain speaking as a philosopher or even a politician could desire. Mr G. J. A. Stern contributed to the 1976 volume of Operational Research Quarterly a paper entitled 'SOSIPing, or Sophistical Obfuscation of Self-Interest and Prejudice'. His plea is for plain language, in spite of the neologism in the title, and for common sense, even if he does call it 'multivariate cost-benefit analysis'. The debate has continued in the Fournal of the Operational Research Society. In the 1978 volume Mr Stern is castigated in a joint paper by S. B. Abrahams (Civil Aviation Authority), A. D. J. Flowerdew (University of Kent at Canterbury), and J. U. M. Smith (Plessey Group). He is also mildly supported by Christopher J. L. Yewlett (Standing Conference on Regional Policy in South Wales, Swansea) who suggests, however, that it has all been said before.

Indeed it has, and not only in the technical work to which Mr Yewlett refers. And it will all need to be said again. For the underlying issues belong to spheres of philosophical and political debate in which no expert can be allowed to blow the final whistle. Mr Stern (International Computers Limited) is not saying that there is no scope for technicality among the tools of social criticism. He is saying that there is also scope for something else. Even if his critics were shown to be right in all their technical objections to his views on the third London airport, he would still have done a useful service in reminding his readers that fulsome rhetoric about the priceless is not the only alternative to the maxim that every man has his implicit price. 